Special Issue: Agricultural Productivity and Sustainability Improvement in Tropical Region

\title{
Physical and Mechanical Characteristics of Edible Film Based on Lesser Yam Starch with Addition of Glycerol and Sodium Tripolyphosphate
}

\author{
Warkoyo Warkoyo $^{1 *}$, Devi Dwi Siskawardani ${ }^{1}$, Anggit Ayu Pradana Siwi ${ }^{1}$, Moch. Wachid ${ }^{1}$, Ivar Zekker ${ }^{2}$ \\ and Jumpen Onthong ${ }^{3}$
}

${ }^{1}$ Department of Food Technology, Faculty of Agriculture and Animal Science, University of Muhammadiyah Malang, Jln. Raya Tlogomas No.246, Malang 65144, Indonesia; ${ }^{2}$ Institute of Chemistry, University of Tartu, Ravila 14a, 50411 Tartu, Estonia; ${ }^{3}$ Department of Earth Science, Faculty of Natural Resources, Prince of Songkla University, 15 Karnjanavanich Rd., Hat Yai, Songkbla 90110, Thailand.

Abstract | Biodegradable food packaging is important to be expanded to reduce the increasing waste in the world. An edible film based on lesser yam (Dioscorea esculenta L. Burkill) has the potential to be innovated and expanded, which contained starch yield up to $21.4 \%$. Several starch properties obstruct edible film characteristics. It cannot tolerate acid and high temperature, which produces suspension with inconsistently gel-forming, syneresis probability of starch gel is high, limited solubility in water. Therefore, starch modification by crosslinking agent addition should be developed. The purpose of this research was to determine the effect of glycerol $\left(\mathrm{C}_{3} \mathrm{H}_{8} \mathrm{O}_{3}\right)$ and Sodium Tripolyphosphate (STPP) - $\mathrm{Na}_{5} \mathrm{P}_{3} \mathrm{O}_{10}$ concentrations on the physical and mechanical edible film. Randomized complete block design (RCBD) factorial was applied with three replications. The $1^{\text {st }}$ factor was glycerol concentration $(17.5,22.5$ and 27.5$) \% \mathrm{v} / \mathrm{w}$ and the $2^{\text {nd }}$ factor was STPP concentration $(0.1,0.2$ and 0.3$) \% \mathrm{w} / \mathrm{v}$. The results indicated a significant interaction between the addition of glycerol and STPP to $\mathrm{pH}(8.12$ to 8.83$)$, thickness $(0.11 \mathrm{~mm}$ to $0.20 \mathrm{~mm})$, solubility (36.31\% to $64.44 \%)$, tensile strength $(1.20 \mathrm{MPa}$ to $1.91 \mathrm{MPa})$, transparency $\left(2.88 \mathrm{~A}_{546} \mathrm{~mm}^{-1}\right.$ to $\left.3.83 \mathrm{~A}_{546} \mathrm{~mm}^{-1}\right)$, and WVTR $\left(13.27 \mathrm{~g}^{-1} \mathrm{~m}^{-2} 24 \mathrm{~h}^{-1}\right.$ to $\left.21.23 \mathrm{~g}^{-1} \mathrm{~m}^{-2} 24 \mathrm{~h}^{-1}\right)$. According to Japanese Industrial Standard JIS Z 1707 (1975), the parameters that meet the standard was the thickness, tensile strength, and elongation.

Received | October 09, 2021; Accepted | December 15, 2021; Published | December 30, 2021

*Correspondence | Warkoyo Warkoyo, Department of Food Technology, Faculty of Agriculture and Animal Science, University of Muhammadiyah Malang, J1.Raya Tlogomas No.246, Malang, 65144, Indonesia; Email: warkoyo@umm.ac.id

Citation | Warkoyo, W., D.D. Siskawardani, A.A.P. Siwi, M. Wachid, I. Zekker and J. Onthong. 2021. Physical and mechanical characteristics of edible film based on lesser yam starch with addition of glycerol and sodium tripolyphosphate. Sarhad Journal of Agriculture, 37(Special issue 1): 144-152.

DOI | https://dx.doi.org/10.17582/journal.sja/2021.37.s1.144.152

Keywords | Biodegradable food packaging, Dioscorea esculenta L. Burkill., Environmentally- friendly technology, Hydrocolloid, Plasticizer

\section{Introduction}

$\mathrm{F}$ ood packaging is necessary to protect food products from physical damage, chemical harm, and microbial infection. Lately, almost all foodpackaging materials have been made up of plastic. Therefore, it needs to develop environmentally friendly food packaging materials that are biodegradable with characteristics similar to plastic, such as edible film.
The main ingredients for forming edible films are biopolymers such as carbohydrates, proteins, and lipids. Tubers that have great potential to be developed as raw material for the edible film is lesser yam (Dioscorea esculenta L. Burkill). Lesser yams have the highest yield of starch $(24.28 \%)$ and starch flour (21.4\%) (Jimenez et al., 2010).

The starch gel is brittle and easily syneresis when 
inconsistent viscosity and gel-forming ability produce a suspension. Chemical modification using the crosslinking method, Sodium Tripolyphosphate (STPP) $-\mathrm{Na}_{5} \mathrm{P}_{3} \mathrm{O}_{10}$ has expanded. The formation of monophosphate starch will make dispersions, which have a higher viscosity and better clarity and stability. The presence of monophosphate significantly reduced gelatinization starch temperature.

Glycerol $\left(\mathrm{C}_{3} \mathrm{H}_{8} \mathrm{O}_{3}\right)$ is a hygroscopic substance that acts as a plasticizer in hydrophilic films, such as gelatin, starch, pectin, and protein-based films production. According to Al-Hasan and Hani (2012), the flexibility and extensibility of edible films will improve, while the strength will decrease by glycerol addition. Ultimately, it will prevent the compactness of basic polymer materials by reducing intermolecular interactions and improving polymer mobility. Therefore, the objective of this research was to investigate the interaction between glycerol and STPP on the physical and mechanical characteristics of edible film.

\section{Materials and Methods}

\section{Analysis of starch content}

Luff School solution formed by dissolving $71.9 \mathrm{~g}$ of anhydrous $\mathrm{Na}_{2} \mathrm{CO}_{3}$ in $300 \mathrm{~mL}$ of heated distilled water. Then, the dissolution of citric acid $(25 \mathrm{~g}$ in $25 \mathrm{~mL}$ of distilled water) was added gradually, followed by a solution of $\mathrm{CuSO}_{4} .5 \mathrm{H}_{2} \mathrm{O}(8 \mathrm{~g}$ in $100 \mathrm{~mL}$ of distilled water). After dissolving, the temperature of the solution was decreased to $40{ }^{\circ} \mathrm{C}$ and left for $30 \mathrm{~min}$, followed up to $500 \mathrm{~mL}$, and left for one night in a dark place.

The flour sample $(1 \mathrm{~g})$ was dissolved in $40 \mathrm{~mL} 3 \% \mathrm{HCl}$ and refluxed for $3 \mathrm{~h}$ at $200{ }^{\circ} \mathrm{C}$ to $250{ }^{\circ} \mathrm{C}$. Afterward, the sample was cooled and neutralized by adding a few drops of $3 \% \mathrm{NaOH}$ assisted by phenolphthalein (PP) indicator until it was pink. Followed acidified process using $3 \% \mathrm{HCl}$ until the $\mathrm{pH}$ is slightly acidic. About $6.5 \mathrm{~mL}$ of filtrate was piped into a sharpened Erlenmeyer, then added $25 \mathrm{~mL}$ of Luff School solution and $20 \mathrm{~mL}$ of distilled water and refluxed for $10 \mathrm{~min}$ (counted when starting boiling). After boiling, then chill in the icebox for a few minutes. The cold sample added $25 \mathrm{~mL}$ of $25 \% \mathrm{H}_{2} \mathrm{SO}_{4}$ and $15 \mathrm{~mL}$ of $20 \% \mathrm{KI}$ solution, then immediately titrated with standardized $\mathrm{Na}_{2} \mathrm{~S}_{2} \mathrm{O}_{3} 0.1 \mathrm{~N}$. The interpolation of $0.5 \%$ starch indicator was implemented during titration and stopped when the colour changed from purple to cloudy white. The control solution was produced by mixing $25 \mathrm{~mL}$ of Luff School solution and $25 \mathrm{~mL}$ of distilled water (without samples). The \% starch was calculated by Equation (1) (SNI 01-2892-1992).

$$
\text { Starch }=\frac{\mathrm{G} * \mathrm{Fp} * 0.9}{\mathrm{~W}} \times 100 \% \ldots
$$

\section{Where;}

G: Mass of starch; W: Mass of sample; FP: Dilution factor.

\section{The thickness of edible film}

The thickness of the film was measured by a micrometer instrument (Herma 0-25 x $0.001 \mathrm{~mm}$ ) with a precision screw of $0.001 \mathrm{~mm}$ (Warkoyo et al., 2014). The micrometer was placed on a compact and clean table, set to zero then the pressing feet were lowered on the sample. Pressing feet were lifted slightly then removed from the first measurement sites to others (total five sites).

\section{Solubility in Water}

The sample was cut (size $1 \mathrm{~cm} \times 1 \mathrm{~cm})$, weighed as the initial weight (W0), and put into a petri dish $(60 \mathrm{~mm} \times 15 \mathrm{~mm})$ containing $15 \mathrm{~mL}$ of distilled water for $10 \mathrm{~min}$. Next, the samples that had been soaked were removed, and the water on the plastic surface was cleaned. Finally, the final sample weighed (W) was measured, and the \% solubility of the edible film was calculated by Equation (2) (Chiumarelli and Hubinger, 2012).

$$
\% \text { Solubility }=\frac{(\mathrm{w} 0)-(\mathrm{W})}{(\mathrm{W} 0)} \times 100 \% \ldots
$$

Where;

W0: Initial weight; W: Final sample weight.

\section{Transparency}

Edible films were cut, recorded the thickness values $(1 \mathrm{~cm} \mathrm{x} 4 \mathrm{~cm}$ ), and put in glass cuvettes (Al-Hasan and Hani, 2012). First, transparency of edible films was observed using a Spectrophotometer Shimadzu UV-1800, Japan (at a wavelength $(\lambda) 546 \mathrm{~nm}$ ). Then the data obtained was calculated by Equation (3).

$$
T=\frac{\text { Absorbance } 546 \mathrm{~nm}}{\mathrm{x}} \ldots .
$$

Where;

T: Transparency; x: Thickness. 
Tensile strength and elongation

Edible films were cut $(20 \mathrm{~mm} \times 50 \mathrm{~mm})$, and both sides were clamped $30 \mathrm{~mm}$ (ASTM D882-12-2012). Universal Testing Machine tested tensile strength and elongation of edible films. Tensile strength values define the maximum pull achievable before edible films become tearing. Tensile strength values were recorded and calculated following Equation (4):

$$
\text { Tensile strength }=\frac{\text { Maximum Force }\left(\mathrm{F}_{\max }\right)}{\text { Area }(\mathrm{A})} \ldots
$$

The percentage of elongation could be observed and calculated by Equation (5):

$$
\text { Elongation }(\%)=\frac{\mathrm{d}_{\text {after }}-\mathrm{d}_{\text {before }}(\mathrm{mm})}{\mathrm{d}_{\text {before }}(\mathrm{mm})} \times 100 \ldots .
$$

Where;

$\mathrm{d}$ : The distance between the clamps of the sample holder before or after the sample was pulled to break.

\section{Water Vapour Transmission Rate (WVTR)}

The film was mounted and covered on a cup containing $2 \mathrm{~g}$ of silica gel. The edge of the cup and the film were covered with wax and weighed (ASTM E96-01-2000). Then, it was put in a plastic jar containing $100 \mathrm{~mL}$ of $40 \% \mathrm{NaCl}$ solution, and the jar was tightly covered. Each hour the cup was weighed and analyzed for $24 \mathrm{~h}$. The generated linear regression equation defined the increasing slope in the cup weight $\left(\mathrm{g} 24 \mathrm{~h}^{-1}\right)$ divided by the film area $\left(\mathrm{cm}^{2}\right)$.

\section{Research design}

Randomized complete block design (RCBD) factorial consisted of two factors with three replications was applied. The $1^{\text {st }}$ factor was glycerol concentration $(17.5,22.5$ and 27.5$) \% \mathrm{v} / \mathrm{w}$ and the $2^{\text {nd }}$ factor was STPP concentration (0.1, 0.2 and 0.3$) \% \mathrm{w} / \mathrm{v}$. Duncan Multiple Range Test (DMRT) was adopted for significant Analysis of Variance (ANOVA) (Adinurani, 2016).

\section{Results and Discussion}

\section{Raw materials analysis}

The results of the raw material test, lesser yams produced starch levels of $80.67 \%$, which consisted of amylose (35.59\%) and amylopectin (45.08\%), while the moisture content (19.33\%) on a dry weight basis. The starch level was equal to the previous research in that the lesser yams starch content was $80.67 \%$.
Still, it was significantly different on the component of amylose (6.79 \%) and amylopectin (73.88 \%) (Pokatong et al., 2014). The harvesting time and weather conditions also affected the starch level. The starch content for tuber harvested in the rainy season is relatively lower because of the high-water content.

\section{pH analysis of edible film solution}

Analysis of variance indicated an interaction between glycerol and STPP significantly on the edible film solutions $\mathrm{pH}$ (Table 1). Whenever the $\mathrm{pH}$ was high, the edible solution was more aqueous. The $\mathrm{pH}$ of the solution is too high caused of gel formation faster and gel formed by much water (Jimenez et al., 2010). STPP is an alkaline phosphate salt, so STPP addition in high concentrations can increase the $\mathrm{pH}$. In addition, glycerol has a low acidity close to the alkaline, same as STPP if glycerol concentration increases, resulting in a higher $\mathrm{pH}$ level.

Table 1: Edible film solution $p H$.

$\begin{array}{lll}\text { Treatment } & \text { pH } & \\ \text { G1S1 (Glycerol 17.5 \% + STPP 0.1\%) } & 8.12 & \text { a } \\ \text { G1S2 (Glycerol 17.5 \% + STPP 0.2 \%) } & 8.16 & \text { b } \\ \text { G1S3 (Glycerol 17.5 \% + STPP 0.3 \%) } & 8.21 & \text { c } \\ \text { G2S1 (Glycerol 22.5 \% + STPP 0.1\%) } & 8.25 & \text { d } \\ \text { G2S2 (Glycerol 22.5 \% + STPP 0.2 \%) } & 8.33 & \text { e } \\ \text { G2S3 (Glycerol 22.5 \% + STPP 0.3 \%) } & 8.35 & \text { f } \\ \text { G3S1 (Glycerol 27.5 \% + STPP 0.1\%) } & 8.64 & \text { g } \\ \text { G3S2 (Glycerol 27.5 \% + STPP 0.2 \%) } & 8.71 & \text { h } \\ \text { G3S3 (Glycerol 27.5 \% + STPP 0.3 \%) } & 8.83 & \text { i }\end{array}$

Remarks: the numbers followed by the same letter in each column shows insignificant differences according to Duncan's test $\alpha 5 \%$.

\section{Edible film thickness}

There was a significant interaction between glycerol and STPP on the edible film thickness (Table 2). The glycerol and STPP separately also had a significant effect on the thickness. Edible film thickness had a positive correlation with glycerol addition. The enhancing glycerol concentration affects the increasing polymer, which complier of the matrix, as the film becomes greater. The thickness of the edible film will affect the appearance, texture, and flexibility when applied to the product.

This is in accordance previous one that plasticizer addition could improve and enhance the polymers that establish the film matrix through dissolved solids in film solution; therefore, thickness level becomes 
high (Warkoyo et al., 2014). The main factor is the ability to bind glycerol water to produce water evaporation rate becoming lower when applied in higher concentration. As a result, glycerol bound some water in the film solution and the edible film directed is thicker (A1-Hasan and Hani, 2012).

Table 2: Edible film thickness, and tensile strength.

\begin{tabular}{|c|c|c|}
\hline Trea & $\begin{array}{l}\text { Thickness } \\
(\mathrm{mm})\end{array}$ & $\begin{array}{l}\text { Tensile } \\
\text { Strength } \\
\text { (MPa) }\end{array}$ \\
\hline 1S1 (Glycerol $17.5 \%+$ STPP $0.1 \%)$ & ) $0.11 \mathrm{a}$ & $1.23 \mathrm{a}$ \\
\hline G1S2 (Glycerol $17.5 \%+$ STPP $0.2 \%$ ) & $0.12 \mathrm{a}$ & $1.78 \mathrm{bc}$ \\
\hline G1S3 (Glycerol $17.5 \%$ + STPP $0.3 \%$ ) & ) $0.13 \mathrm{ab}$ & $1.90 \mathrm{c}$ \\
\hline G2S1 (Glycerol $22.5 \%$ + STPP $0.1 \%$ ) & ) $0.14 \mathrm{~b}$ & $1.22 \mathrm{a}$ \\
\hline G2S2 (Glycerol $22.5 \%+$ STPP $0.2 \%$ ) & $0.15 \mathrm{~b}$ & $1.20 \mathrm{a}$ \\
\hline G2S3 (Glycerol $22.5 \%$ + STPP $0.3 \%$ ) & $0.16 \mathrm{bc}$ & $1.90 \mathrm{c}$ \\
\hline G3S1 (Glycerol $27.5 \%+$ STPP $0.1 \%$ ) & $0.17 \mathrm{bc}$ & $1.35 \mathrm{a}$ \\
\hline G3S2 (Glycerol $27.5 \%+$ STPP $0.2 \%$ ) & 18 & $1.39 \mathrm{ab}$ \\
\hline 33S3 (Glycerol 27.5 \% + STPP $0.3 \%$ ) & $0.20 \mathrm{~d}$ & 1.91 \\
\hline
\end{tabular}

Remarks: the numbers followed by the same letter in each column shows insignificant differences according to Duncan's test $\alpha 5 \%$.

Sodium tripolyphosphate (STPP) concentration affected the edible film thickness. The concentration of $0.3 \%$ sodium tripolyphosphate produced the thickest edible film (Table 2). According to Htwe (2011), there were many broken starch granules during the heating process; STPP addition would reduce damaged granules; thus, water molecules were trapped inside the starch granules, resulting in a compact paste. Furthermore, the polymers that compiler the film matrix is also bigger. This finding correlated to the phosphate substitution degree on the starch hydroxyl cluster. Therefore, the thickest edible film on $0.3 \%$ expected an optimum substitution process of phosphate cluster on the hydroxyl cluster. The mechanism was one phosphate cluster from sodium tripolyphosphate would substitute one of the hydroxyl clusters of starch and form the monoesther. Whenever this mechanism becomes frequent, the starch becomes more viscous and will produce a thicker edible film. The thickness of the edible film was related to the viscosity of the starch solution (Htwe, 2011). Moreover, higher viscosity will produce thicker edible film than lower dense solution starch. In addition, there was a positive correlation between amylose content in starch to the viscosity of solution starch (Souza et al., 2012).
Tensile strength of edible film

The tensile strength decreased with the increasing concentration of glycerol and STPP (Table 2). This finding is caused by glycerol as a constituent with low molecular weight can interrupt among polymers. Previous studies identified that reducing the force among molecules through polysaccharides chain by glycerol addition so that the reduction in starch bonds increases and the strain decrease and, consequently, the tensile strength is lower (Chiumarelli and Hubinger, 2012). According to Muscat et al. (2012), increasing glycerol concentration would reduce tensile strength value and increase elongation.

Glycerol can enter the polymer chain; it disrupts the starch compactness, reduces the intermolecular interactions, and increase polymer mobility. The ratio of glycerol: starch can affect tensile strength, higher glycerol level, or greater glycerol starch ratio, produce bonds between polymers become weaker, as the result tensile strength of edible films become stronger (Warkoyo et al., 2014).

The tensile strength of edible film increased through STPPconcentration enhancement. The tensile strength of edible film due to the treatment of sodium tripolyphosphate concentrations ranged from $2.22 \mathrm{MPa}$ to $5.63 \mathrm{MPa}$. The film's tensile strength value increases through crosslinking density due to the reaction between the hydroxyl group and crosslinking agent to form hydrogen bonds (Detduangchan et al., 2014; Owusu-Darko et al., 2014; Yulianti and Ginting, 2012). Similar results were reported by Kaur et al. (2006) that the value of tensile strength of corn starch-edible film crosslinking was higher than corn starch without modified crosslinking. Technically, the optimum concentration of crosslinking agents is an essential factor in determining modified starch films' mechanical characteristics. Low concentrations of the crosslinking agent are insufficient for the crosslinking process between starch molecules to increase the film's tensile strength. While, at high concentrations, there is crosslinking excess, which limits the mobility of starch molecules can cause a decrease in the tensile strength of edible films produced (Aprianita et al., 2014; Detduangchan et al., 2014; Liu et al., 2016).

\section{Elongation of edible film}

The addition of plasticizers is essential to improve the flexibility of edible film by decreasing the polymer chain length (Muscat et al., 2012). Based on Table 3, 
the glycerol and STPP concentrations separately significantly affected the edible film elongation.

Table 3: Edible film elongation.

\begin{tabular}{llc} 
Treatment & \multicolumn{2}{c}{ Elongation (\%) } \\
Glycerol (\%) & & \\
17.5 & 14.29 & $\mathrm{a}$ \\
22.5 & 17.59 & $\mathrm{~b}$ \\
27.5 & 21.18 & $\mathrm{c}$ \\
STPP(\%) & & \\
0.1 & 16.48 & $\mathrm{~ns}$ \\
0.2 & 17.55 & $\mathrm{~ns}$ \\
0.3 & 17.03 & $\mathrm{~ns}$
\end{tabular}

Remarks: the numbers followed by the same letter in each column shows insignificant differences according to Duncan's test $\alpha 5 \%$.

Elongation of edible films increases with the addition of plasticizers (glycerol), which can also cause long intermolecular forces to decrease, thus increasing mobility between polymers, and consequently, the film becomes more elastic and flexible. The addition of glycerol will affect the chain configuration style; the free chain moves to soften the forces that occur between polymers, the elasticity of polymer becomes high (Su et al., 2010).

Elongation tends to be stable with the addition of STPP due to the reaction between starch molecules (monophosphate). In addition, the formation of monophosphate starch can interfere with the expansion and rupture of starch granules due to the heating process, resulting in reducing the gelatinization temperature. Thus, it resulted in a compact paste, increasing the edible film mobility and elongation.

The results indicated that the elongation is inversely proportional to the tensile strength value. A large tensile strength will affect the elongation value to be smaller. Conversely, decreasing tensile strength would increase elongation (Warkoyo et al., 2014). This opinion is in line with Dick et al. (2015), who reported that tensile strength decreased from $17.75 \mathrm{MPa}$ to $9.44 \mathrm{MPa}$, resulting in an elongation value that increased from $1.93 \%$ to $10.78 \%$. The amylose content in starch contributed to the film elongation value (Alves et al., 2007). The high percentage of elongation defines that edible film has great flexibility, is easy to apply, and has a longer shelf life.

The amylose structure is very stable, with a strong molecular orientation, forming a denser film than amylopectin (Alves et al., 2007). The tight structure is through to produce a small elongation value so that a greater force $(\mathrm{N})$ is needed to achieve the maximum stress that affects the tensile strength to be high and elongation value is low.

Due to the treatment of various sodium tripolyphosphate concentrations, the elongation value ranged from $19.20 \%$ to $34.78 \%$. Gutierrez et al. (2015) found that the addition of crosslinking agents did not significantly affect elongation. A $3 \%$ sodium trimethaphosphate concentration produced elongation of $38 \%$ and $40 \%$, respectively, for the edible film of cassava starch without modification and modification. At the same time, Velickova et al. (2015) reported that the concentration of sodium tripolyphosphate affected decreasing the elongation of chitosan-based edible film.

\section{Edible film transparency}

The combination of glycerol and STPP resulted significantly affects the transparency, which indicates the brightness of edible films (Table 4). A higher transparency value indicates the poor brightness/ clarity level, and the absorbancy value is high (AlHasan and Hani, 2012). In addition, transparency is related to the thickness and materials concentration proportionally. Therefore, the light quantity will be more absorbed in a thicker or greater material concentration.

Several factors could influence film transparency, one of which is film thickness. It will increase the diffusion of light so that the object of the edible film will appear more turbid, and the brightness will be lower. In addition, the thicker edible film will give a colour that is not transparent.

The transparency value of edible film tends to decrease with the addition of sodium tripolyphosphate. These results indicate that the concentration of sodium tripolyphosphate optimally can make the edible film more transparent, a situation which was caused by the degree of crosslinking agents dispersed in the starch matrix so that the clarity of starch increases the transparency of the film produced(Detduangchan etal., 2014). Furthermore, there was increased transparency in edible films made from modified rice crosslinking starch. The obtained film becomes more transparent at a concentration of sodium trimethaphosphate $3 \%$ than $12 \%$ sodium trimetaphosphate. 
Table 4: Edible film transparency, solubility and WVTR.

\begin{tabular}{|c|c|c|c|c|c|c|}
\hline \multirow{2}{*}{$\begin{array}{l}\text { Treatment } \\
\text { G1S1 (Glycerol } 17.5 \%+\text { STPP } 0.1 \% \text { ) }\end{array}$} & \multicolumn{2}{|c|}{ Transparency $\left(\mathrm{A}_{546} \mathrm{~mm}^{-1}\right)$} & \multicolumn{2}{|c|}{ Solubility (\%) } & \multicolumn{2}{|c|}{ WVTR $\left(\mathrm{g}^{-1} \mathrm{~m}^{-2} 24 \mathrm{~h}^{-1}\right)$} \\
\hline & 2.88 & $\mathrm{a}$ & 64.44 & $\mathrm{~d}$ & 13.27 & $\mathrm{a}$ \\
\hline G1S2 (Glycerol $17.5 \%+$ STPP $0.2 \%$ ) & 2.96 & $\mathrm{a}$ & 57.29 & $\mathrm{~cd}$ & 14.33 & $\mathrm{ab}$ \\
\hline G1S3 (Glycerol 17.5 \% + STPP $0.3 \%$ ) & 3.34 & $\mathrm{~b}$ & 56.39 & c & 15.13 & $\mathrm{~b}$ \\
\hline G2S1 (Glycerol $22.5 \%+$ STPP $0.1 \%)$ & 3.50 & $\mathrm{bc}$ & 55.62 & c & 15.66 & $\mathrm{~b}$ \\
\hline G2S2 (Glycerol $22.5 \%+$ STPP $0.2 \%$ ) & 3.54 & c & 52.94 & $\mathrm{bc}$ & 17.52 & $\mathrm{bc}$ \\
\hline G2S3 (Glycerol $22.5 \%+$ STPP $0.3 \%$ ) & 3.64 & $\mathrm{~cd}$ & 46.67 & $\mathrm{~b}$ & 18.31 & c \\
\hline G3S1 (Glycerol $27.5 \%+$ STPP $0.1 \%$ ) & 3.76 & cde & 46.43 & $\mathrm{~b}$ & 19.11 & $\mathrm{~cd}$ \\
\hline G3S2 (Glycerol $27.5 \%$ + STPP $0.2 \%$ ) & 3.80 & de & 41.38 & $\mathrm{~b}$ & 19.90 & $\mathrm{~d}$ \\
\hline G3S3 (Glycerol $27.5 \%+$ STPP $0.3 \%$ ) & 3.83 & e & 36.31 & a & 21.23 & e \\
\hline
\end{tabular}

Remarks: the numbers followed by the same letter in each column shows insignificant differences according to Duncan's test $\alpha 5 \%$.

\section{Solubility of edible film}

There was a combination between glycerol and STPP significantly on the edible film solubility (Table 4). The solubility value had a positive correlation to the glycerol and STPP concentrations, and it was very higher (36.31\% to $64.44 \%)$ from previous research (17.18 \%) (Krisna, 2011). According to Muscat et al. (2012), solubility increases as edible film constituents' hydrophilic component increases. In addition, a greater number of hydroxyl groups resulted in the increasing water absorbed level was getting faster (Souza et al., 2012).

Glycerol can play a role in increasing the solubility of starch-based edible films. The glycerol concentration enhancement produces greater solubility of edible film because glycerol is more hydrophilic than starch. The high solubility of the edible film is caused by plasticizer affinity (including sorbitol), which is strong against water molecules, and low molecular weight can be easier to enter among polymer chains; consequently, the volume of free space increases. According to a previous experiment, the hydrophilic edible film-forming material is more soluble in water than hydrophobic materials, such as beeswax, paraffin, and wax.

The solubility of starch-based edible films can be influenced by the content of amylose and amylopectin in starch (Shit and Shah, 2014). Edible films made from starch with high amylose content have good flexibility and are more water-soluble due to the amylose's characteristic, which is very soluble in water, in contrast to the properties of amylopectin less dissolves in water. According to Warkoyo et al. (2014), the solubility of edible film in water can also be influenced by the ratio of glycerol: starch used.
Solubility will decrease with the increasing starch usage, or the ratio between glycerol: starch is low.

Solubility of edible film tends to decrease with the addition of sodium tri-polyphosphate. This is because STPP existence acts as a cross-linker. Crosslinking causes the bonds between molecules that are covalent bonds in modified starch to be stronger than pure starches, which only consist of hydrogen bonds. This cross bond can bind water more strongly; thus, bound water is not easy to be released; as a result, the solubility value is getting smaller. According to Kaur et al. (2006) findings, the crosslinking agent's usage on various potato starch varieties can reduce the solubility in water due to an increase in crosslink density.

\section{WVTR of edible film}

There was a significant interaction between glycerol and STPP on the WVTR value of edible films produced (Table 4). Enhancement of transmission of water vapor as greater glycerol and STPP concentration applied. The water vapor transmission rate (WVTR) height value refers to the component passing through the edible film. An excellent edible film must not be easily passed by water or steam and has a low WVTR value.

Films made from hydrocolloid compounds tend to be lesser for water vapor transmission rate because they are hydrophilic. The addition of glycerol will improve the hydrophilic properties of the film formed because glycerol has more hydrophilic properties than edible film constituents. The addition of hydrophilic plasticizers in edible films can increase the water vapor transmission rate. The ratio of glycerol will follow increased glycerol: starch enhancement, which 
causes free hydroxyl groups to liven up and influence the increasing water vapor transmission rate (Perez et al., 2012; Warkoyo et al., 2014).

The rate of water vapor transmission increases because of sodium tripolyphosphate concentration. The increasing of STPP causes the phosphate group to form higher; as a result, the hydrophilic nature of the edible film is enhanced, and WVTR also liven up. According to Perez et al. (2012), edible film crosslinking starch tends to have greater value caused by the increasing hydrophilic of the starch system due to the number of phosphate groups enhancement. A similar phenomenon reported by Gutierrez et al. (2015), on an edible film of sweet yam's starch (Dioscorea trifida L.f.) crosslinked with sodium trimetaphosphate showed a greater value of water vapour transmission rate $\left(3 \times 10^{-11} \mathrm{~g}^{-1} \mathrm{~m}^{-2} 24 \mathrm{~h}^{-1}\right)$ than films without crosslinking $\left(1.8 \times 10^{-11} \mathrm{~g}^{-1} \mathrm{~m}^{-2} 24 \mathrm{~h}^{-1}\right)$.

In addition, STPP intercalation can increase the thickness of the formed edible film, consequently increasing WVTR. The water vapour transmission rate was in line with the thickness level of film used (Velickova et al., 2015). Whenever the thickness of the film is high, the water vapour transmission rate is greater. For example, chitosan-based multi-layer film modified with sodium tripolyphosphate crosslinking with beeswax showed the thickness of $114 \mu \mathrm{m}$ $(0.114 \mathrm{~mm})$ and reaching the highest water vapour transmission rate $\left(4.8 \times 10^{-11} \mathrm{~g}^{-1} \mathrm{~m}^{-2} 24 \mathrm{~h}^{-1}\right)$ compared to the treatment of chitosan: wax with a thickness of $60 \mu \mathrm{m}(0.06 \mathrm{~mm})$ resulted in the lowest water vapor transmission rate $\left(1.7 \times 10^{-11} \mathrm{~g}^{-1} \mathrm{~m}^{-2} 24 \mathrm{~h}^{-1}\right)$. According to Gutierrez et al. (2015), the enhancement of thickness in films is positively correlated with the water vapour transmission rate due to changes in conditions in some of the water vapour pressure in the film.

\section{Conclusions and Recommendations}

The results showed a significant interaction between the addition of glycerol and STPP to $\mathrm{pH}$ (8.12 to 8.83), thickness (0.11 mm to $0.20 \mathrm{~mm}$ ), solubility (36.31\% to $64.44 \%)$, tensile strength (1.20 MPa to1.91 MPa), transparency $\left(2.88 \mathrm{~A}_{546} \mathrm{~mm}^{-1}\right.$ to 3.83 $\left.\mathrm{A}_{546} \mathrm{~mm}^{-1}\right)$, and WVTR $\left(13.27 \mathrm{~g}^{-1} \mathrm{~m}^{-2} 24 \mathrm{~h}^{-1}\right.$ to 21.23 $\left.\mathrm{g}^{-1} \mathrm{~m}^{-2} 24 \mathrm{~h}^{-1}\right)$. The parameters that meet the standard Japanese Industrial Standard JIS Z 1707 (1975) were thickness, tensile strength, and elongation. Therefore, the best treatment is G3S3 (27.5\% glycerol and $0.3 \%$ STPP) with thickness $(0.20 \mathrm{~mm})$, tensile strength $(1.91 \mathrm{MPa})$, and elongation $(21.18 \%)$.

\section{Novelty Statement}

The novelty of this study is indicated by the formulation and proportion of glycerol and STPP at the best treatment with based raw material lesser yam starch. In other words, the result of the variables test (thickness, tensile strength, and elongation) meets the standard of JIS. Therefore, the following research needs a new formulation and raw material to improve the quality of the edible film.

\section{Author's Contribution}

WW: Conceptualized and designed the study, elaborated the intellectual content, performed literature search, manuscript preparation, manuscript revision.

DDS: Elaborated the intellectual content, performed literature search, data acquisition, manuscript review, and manuscript revision.

AAPS: Carried out experimental studies, data acquisition, and data analysis.

MW: Data acquisition, data analysis, and manuscript review.

IZ: Elaborated the intellectual content, performed literature search, manuscript review, and guarantor.

JO: Performed literature search, data acquisition, and manuscript preparation.

All authors read and approved the final manuscript.

\section{Confict of interest}

The authors declare that there is no conflict of interest regarding the publication of this article.

\section{References}

Adinurani, P.G. 2016. Design and analysis of agro trial data: Manual and SPSS. Plantaxia, Yogyakarta, Indonesia.

A1-Hasan A.A. and N.M. Hani. 2012. Starch gelatin edible films: water vapor permeability and mechanical properties as affected by plasticizers. Food Hydrocoll., 26(1):108117. https://doi.org/10.1016/j.foodhyd.2011.04.015

Alves, V.D., S. Mali, A. Beleia and M.V.E. Grossmann. 2007. Effect of glycerol and amylose enrichment on cassava starch film 
properties.J. Food Eng., 78(3): 941-946. https:// doi.org/10.1016/j.jfoodeng.2005.12.007

Aprianita A., T. Vasiljevic, A. Bannikova and S. Kasapis. 2014. Physicochemical properties of flours and starches derived from traditional Indonesian tubers and roots. J. Food Sci. Technol., 51(12): 3669-3679. https://doi. org/10.1007/s13197-012-0915-5

ASTM D882-12. 2012. Standard test method for tensile properties of thin plastic sheeting. ASTM International, West Conshohocken, PA. (https://www.academia.edu/35535373/ Standard_Test_Method_for_Tensile_ Properties_of_Thin_Plastic_Sheeting_1)

ASTM E96-00e1.2000. Standard test methods for water vapor transmission of materials. ASTM International,West Conshohocken,PA.(https:// www.researchgate.net/publication/336879226_ Standard_Test_Methods_for_Water_Vapor_ Transmission_of_Materials_1ASTM D88212. 2012. Standard Test Method for Tensile Properties of Thin Plastic Sheeting. ASTM International, West Conshohocken, PA).

Badan Standarisasi Nasional. 1992. SNI 01-28921992 How to test sugar. Badan Standarisasi Nasional, Jakarta. Indonesia (https://dokumen. tips/documents/sni-01-2892-1992-cara-ujigula-madu.html).

Chiumarelli, M. and M.D. Hubinger. 2012. Stability, solubility, mechanical and barrier properties of cassava stach-Carnauba wax edible coatings to preserve fresh-cut apples. Food Hydrocoll., 28(1): 59-67. https://doi. org/10.1016/j.foodhyd.2011.12.006

Detduangchan N.,W. Sridach and T.Wittaya. 2014. Enhancement of the properties of biodegradable rice starch films by using chemical crosslinking agent. Int. Food Res. J., 21(3): 1225-1235.

Dick, M., T.M.H. Costa, A. Gomaa, M. Subirade, A.O. Rios and S.H. Flores. 2015. Edible film production from chia seed mucilage: effect of glycerol concentration on its physicochemical and mechanical poperties. Carbohydr. Polym., 130: 198205. https://doi.org/10.1016/j. carbpol.2015.05.040

Gutierrez T.J., M.S. Tapia, E. Perez and L. Fama. 2015. Structural and mechanical properties of edible films made from native and modified cush-cush yam and cassava starch. Food Hydrocoll., 45: 211-217. https://doi. org/10.1016/j.foodhyd.2014.11.017
Htwe, T.M.M. 2011. Studies on some properties of starch from taro corm. Uni. Res. J., 4(3): 253-265.

Jimenez, A., M.J. Fabra, P. Talens and A. Chiralt, 2010. Effect of lipid self-association on the microstructure and physic properties of hydroxypropyl-methylcellulose edible films containing fatty acids. Carbohydr. Polym., 82(3): 585-593. https://doi.org/10.1016/j. carbpol.2010.05.014

Kaur L.,J. Singh and N. Singh. 2006. Effect of crosslinking on some properties of potato (Solanum tubersum L.) starches J. Sci. Food Agric., 86(12): 1945-1954. https://doi.org/10.1002/jsfa.2568

Krisna D.D.2011. Regelatination and hydrothermic modification effects to physical properties in edible film based red bean (Vigna angularis sp.) starch edible film production. Thesis. Ilmu dan Teknologi Pertanian Universitas Muhammadiyah Malang, Malang, Indonesia. https://core.ac.uk/download/pdf/11734993.pdf

Liu Y., B. Sun, Z.Wang and Y.Ni.2016. Mechanical and water vapor barrier properties of bagasse hemicellulose-based films. Bioresources, 11(2):4226-4236. https://doi.org/10.15376/ biores.11.2.4226-4236

Muscat, D., B. Adhikari, R. Adhikari and D.S. Chaudhary. 2012. Comparative study of film forming behaviour of low and high amylose starches using glycerol and xylitol as plasticizers J. Food Eng., 109(2):189-201. https://doi. org/10.1016/j.jfoodeng.2011.10.019

Owusu-Darko, P.G., A. Paterson, A. and E.L. Omenyo, 2014. Cocoyam (corms and cormels) - an underexploited food and feed resource. J. Agric. Chem. Environ., 3(1): 22-29. https:// doi.org/10.4236/jacen.2014.31004

Perez, E., X. Segovia, M.S. Tapia and M. Schroeder. 2012. Native and cross-linked modified Dioscorea trifida (cush-cush yam) starches as bio-matrices for edible films. J. Cell. Plast., 48(6): 545-556. https://doi.org/10.1177/0021955X12445603

Pokatong, W.D.R., C. Lestari and T.S. Mastuti. 2014. Utilization of Dioscorea esculenta Lour. Burkill with addition of plasticizers as edible coating on strawberries. Prosiding Seminar Nasional Sains dan Teknologi (SNST) ke-5, Semarang, Indonesia 1:86-95.

Shit, S.C. and P.M. Shah. 2014. Edible polymers: Challenges and opportunities. J. Polym., (ID 427259):1-13. https://doi. 
org/10.1155/2014/427259

Souza,A.C., R.Benze, E.S.Ferrão, C.Ditch,A.C.V. Coelho and C.C. Tadini. 2012. Cassava starch biodegradable films: In fluence of glycerol and clay nanoparticles content on tensile and barrier properties and glass transition temperature. LWT - Food Sci. Technol., 46(1): 110-117. https://doi.org/10.1016/j.lwt.2011.10.018

Su, J.F., Z. Huang, X.Y. Yuan, X.Y. Wang and M. Li. 2010. Structure and properties of carboxymethyl cellulose/soy protein isolate blend edible films crosslinked by Maillard reactions. Carbohydr. Polym., 79 (1): 145-153. https://doi.org/10.1016/j.carbpol.2009.07.035

Velickova, E., E. Winkelhausen, S. Kuzmanova,
M. Moldao-Martins and V.D. Alves. 2015. Characterization of multilayered and composite edible films from chitosan and beeswax. Food Sci. Technol. Int., 21(2):83-93. https://doi. org/10.1177/1082013213511807

Warkoyo, B. Rahardjo, D.W. Marseno and J.N.W Karyadi. 2014. Physical, mechanical and barrier properties of Xanthosoma saggittifolium stach based edible film incorporated with potassium sorbate. Agritech., 34(1):72-81.

Yulianti, R. and E. Ginting. 2012. Physical characteristics of edible films derived from tubers starches with addition of plasticizers. Penelitian Pertanian Tanaman Pangan., 31(2): 131-136. 